\title{
MANAGEMENT OF WILD SLOTHS IN AN ANTHROPIZED AREA AT ATLANTIC FOREST
}

\author{
Martha Lima Brandão', Marina Carvalho Furtado ${ }^{1}$, Daniela Duarte de Albuquerque ${ }^{2}$, José \\ Luís Passos Cordeiro ${ }^{1}$, Maria Cristina da Silva Lourenço ${ }^{3}$ \& Fabiano Borges Figueiredo ${ }^{*}$
}

${ }^{1}$ Fundação Oswaldo Cruz, Fiocruz Mata Atlântica, Estrada Rodrigues Caldas, no 3400, Curicica, CEP 22713-375, Rio de Janeiro, RJ, Brazil.

${ }^{2}$ Universidade Federal Fluminense, Programa de Pós-Graduação em Clínica e Reprodução Animal, Av. Almirante Ary Parreiras, nº 507, Icaraí, CEP 24220-000, Niterói, RJ, Brazil.

${ }^{3}$ Fundação Oswaldo Cruz, Instituto Nacional de Infectologia Evandro Chagas, Laboratório de Bacteriologia e Bioensaios, Av. Brasil, no 4365, Manguinhos, CEP 21040-360, Rio de Janeiro, RJ, Brazil.

${ }^{4}$ Fundação Oswaldo Cruz, Instituto Carlos Chagas, Laboratório de Biologia Celular, Rua Professor Algacyr Munhoz Mader, nº 2135-2261, Cidade Industrial, CEP 81310-020, Curitiba, PR, Brazil.

E-mails: brandaomarthal@gmail.com; marinafurt@yahoo.com.br; vetdaniduarte@gmail.com; jlpcordeiro@gmail. com; cristina.lourenco@ini.fiocruz.br; fabiano.figueiredo@fiocruz.br (*corresponding author)

\begin{abstract}
Bradypus variegatus Schinz, 1825, is one of the four extant three-toed sloths. We report data on the management of free-living sloths in the Atlantic Forest Fiocruz Campus, Rio de Janeiro, Brazil. From 2013 to 2017, we have captured 23 sloths in hazard. The animals were microchipped and released in Pedra Branca State Park. Here we also report two recaptures, a mating observation and a case of electrocution, highlighting the importance of management for improving the knowledge in biology and conservation of this species.
\end{abstract}

Keywords: Atlantic Forest; Bradypus variegatus; conservation; translocation and release.

The brown-throated sloth, Bradypus variegatus Schinz, 1825, is one of the four extant three-toed sloths. It is an arboreal mammal that feeds mainly on leaves, branches and sprouts of various plants, frequently Moraceae (Chiarello \& Members of the Edentate Specialist Group 2008), Cecropiaceae and Clethraceae (Urbani \& Bosque 2007). Sexual dimorphism allows gender identification of adults, as males present a mid-dorsal speculum in the interscapular region (Figure 1). Sex differentiation in juveniles and cubs is only possible by critical examination of the external genitalia (Pocock 1924, Britton 1941, Divers 1986, Xavier 2007).

Active at night and day, sloths only descend to the ground to move to other trees or to defecate, once or twice a week (Nowak 1999). Once on the floor, they are vulnerable and easily captured by other wild animals or men (Walker 1991, Reid 1997, Haissen 2010). They can spend up to $82 \%$ of their time resting, and their average daily movement is $23.3 \mathrm{~m}$ (Queiroz 1995). Studies on the home range of adult brown throated sloths are somewhat variable in their findings. Home ranges varied from 0.5 to 9 ha (Montgomery \& Sunquist 1975, Gilmore et al. 2001, Hayssen 2010, Neam \& Lacher 2015). Pauli \& Perry (2012) found even greater variation (0.19 - 19.9 ha), but all available estimates are relatively smaller than expected for a medium- 
sized mammal (Neam \& Lacher 2015).

The distribution of $B$. variegatus ranges from Honduras to the West coast of Ecuador, from Colombia and Venezuela, through the east of Andes and forest areas in Ecuador, Peru, Bolivia and Brazil (Moraes-Barros et al. 2014). Bradypus variegatus is listed in CITES Appendix II (CITES 2017), and categorized as Least Concern on the IUCN Red List due to the fragmentation and destruction of the Atlantic Forest (Moraes-Barros et al. 2014). However, this species is considered extinct in some regions, as in the state of Paraná (Mikich \& Bérnils 2004).

The B. variegatus were found in many cities cohabiting with humans as at Paraíba Federal University, whereitlivesina densityofapproximately 2.26 animals/ha (Silva et al. 2017). Within the city of Rio de Janeiro, Rio de Janeiro state, Brazil, it is currently found in the neighborhood of the Atlantic Forest Fiocruz Campus (CFMA-FIOCRUZ), often in hazard situations. This Campus is located at the boundaries of the Pedra Branca State Park (PEPB), the largest urban forest fragment in the Americas (Figure 2). It is a protected area which boundaries currently represents one of the main fronts of urban growth in the city of Rio de Janeiro.

Here we report data on the management of free-living B. variegatus individuals in the CFMA/ FIOCRUZ area from 2013 to 2017. We only capture animals in hazard situations. The animals were captured manually, with the aid of leather gloves. Thereby we only studied animals that were vulnerable and may be easily captured by other wild animals or men.

The staff of the Project for Fauna Management and Zoonoses Surveillance (PMVS/CFMAFIOCRUZ) is frequently called to remove sloths out of a garden or from the street, and sometimes we receive animals that were captured by pedestrians. We use physical restraint to transport
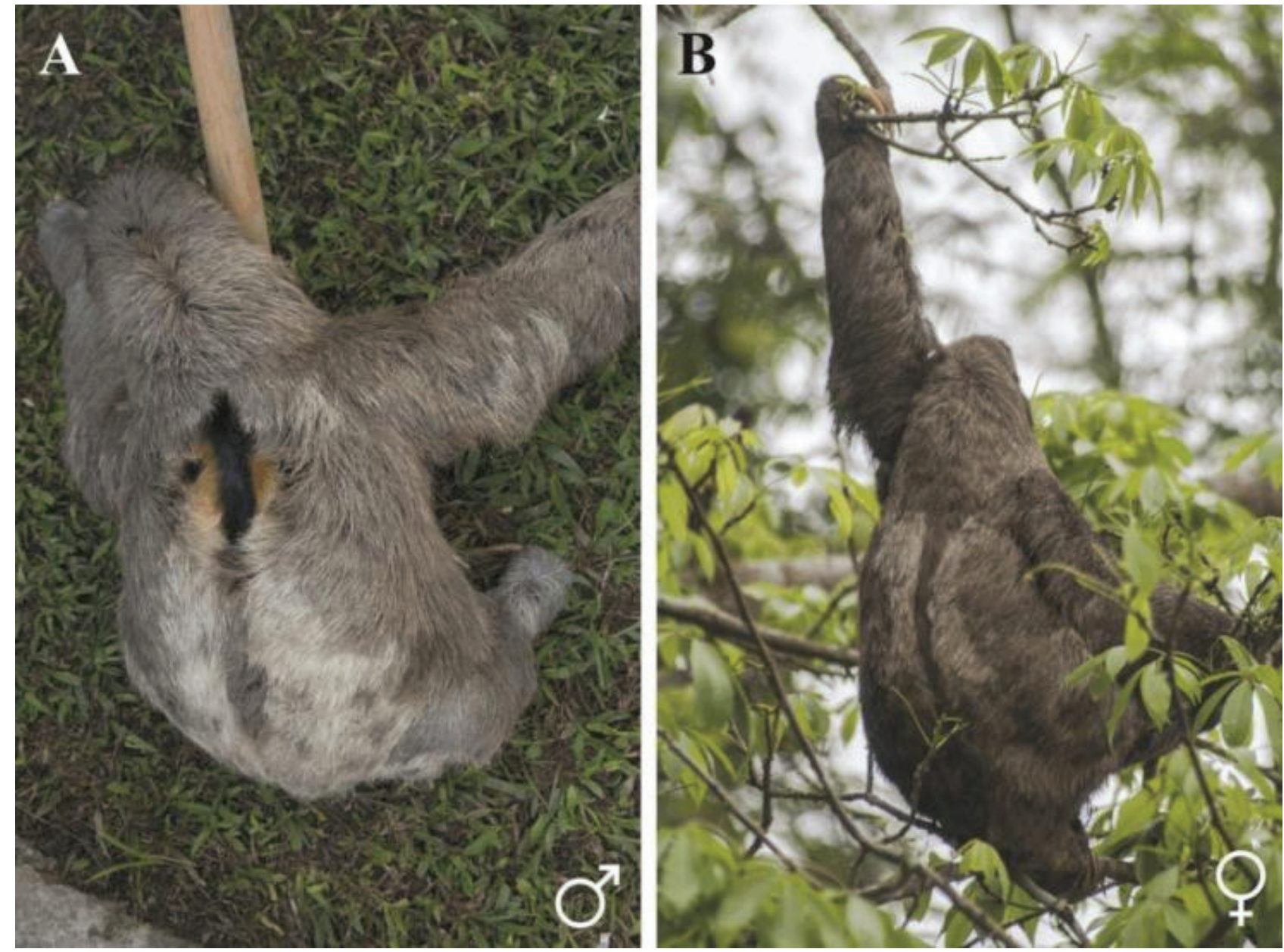

Figure 1. Dorsal view of an adult male (A) and female (B) of Bradypus variegatus captured in the Campus Fiocruz Mata Atlântica, State of Rio de Janeiro, Brazil. 


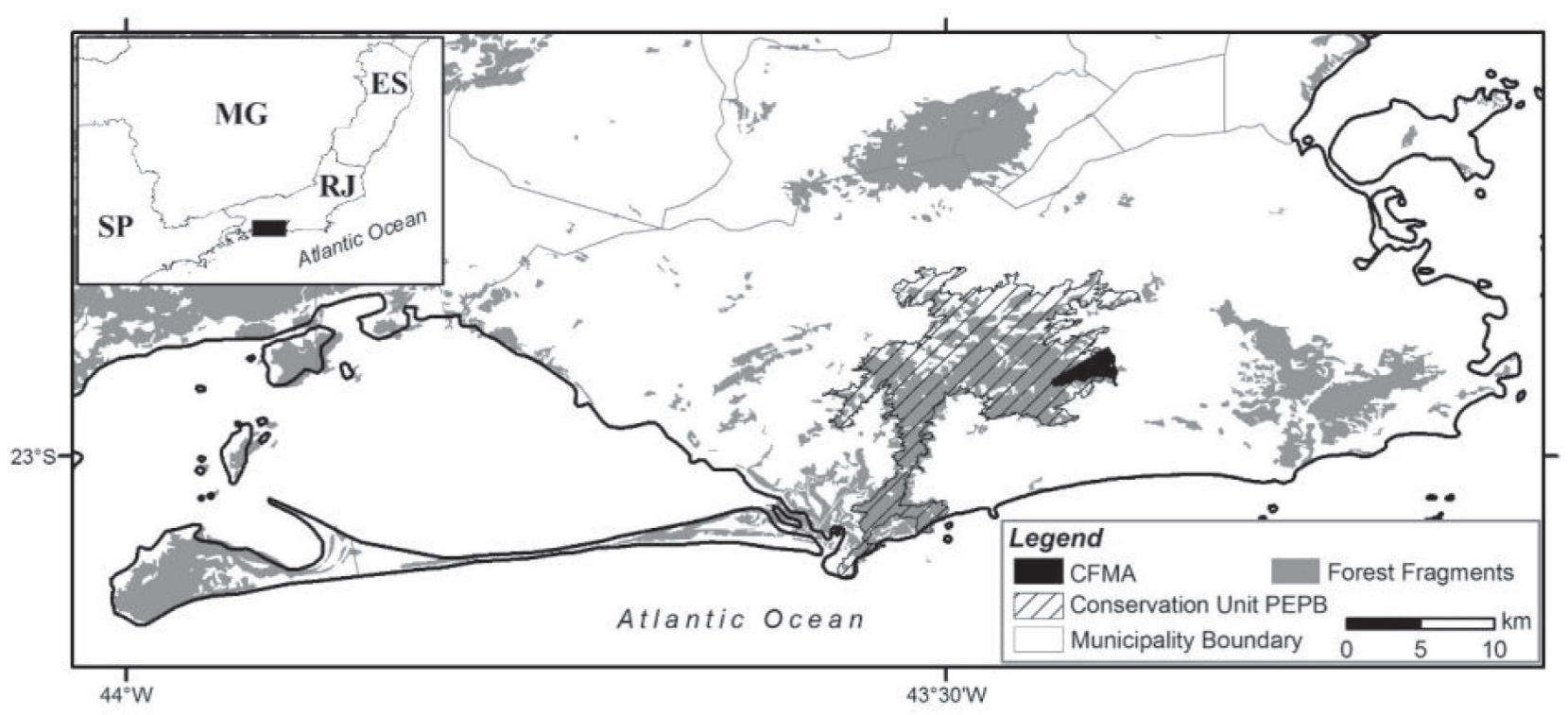

Figure 2. Study area at the Atlantic Forest Fiocruz Campus (CFMA), in Rio de Janeiro City, Southeast Brazil, in the surrounding of the Parque Estadual da Pedra Branca (PEPB).

the animals and collect biological samples. We collect morphological data: total length, thoracic circumference, tail length, wingspan (measured with the aid of a measuring tape) and weight (measured with a $10 \mathrm{~kg}$ Pesola) (Table 1), ectoparasites and blood sample for zoonoses investigation. The sloths are microchipped (Destron Fearing ${ }^{\mathrm{TM}}$, ISO 11784) and released as soon as all samples are collected. These samples are saved for future analyses at Oswaldo Cruz Foundation at National Infectology Institute (INI/ FIOCRUZ), Rio de Janeiro state, Brazil.

Animals are always released at PEPB a 12.492 protected hectares that is the known area where these species leave and offers food availability (CFMA has a floristic survey of the area and known species of its diet are present at PEPB). The release points are carefully chosen by the staff with characteristics like canopy height, canopy connection, and always in a feeding tree out of the common way of pedestrians (Santos et al. 2016). The release point is usually different from the capture point since the animals are usually captured on anthropized areas near roads with circulation of vehicles, people and domestic animals. The management methods are approved by SISBIO ( $\mathrm{n}$. 40539-4) and by the Committee for Ethics in the use of Animals - CEUA/FIOCRUZ (n. LW-61/14).

Since 2013, we have chipped/captured 19 individuals of $B$. variegatus, including 11 males (three juveniles), five females and three individuals that were not sexed. Their average morphological measures were based on 13 adult individuals excluding cubs and individuals that were not sexed (Table 1). From all captured sloths we collected from one to three ticks in 10 animals and 12 blood samples.

On June 12, 2013 one adult male was captured close to the CFMA-FIOCRUZ main building. This animal (Sloth 3) was identified with a microchip (Destron Fearing ${ }^{\mathrm{TM}}$, ISO 11784) and then released $632 \mathrm{~m}$ from the capture point (Figure 3). The same sloth (Sloth 3) was recaptured about three years later, on March 07, 2016, 766 m east of the release point and $168 \mathrm{~m}$ south of the previous capture point. It presented the same body measures and instead of good appearance it seems to be blind. The right eye presented corneal opacity but was apparently healthy in the first capture three years before (Figure 4). Another male (Sloth 16) was captured on July 27, 2016, and recaptured 33 days later (August 29, 2016), $604 \mathrm{~m}$ north away from the release point and $619 \mathrm{~m}$ from the previous capture point (Figure 3). The second release was made far from the recapture point, as the latter is an area of intensive human activity and different from the prior point, where there is a deposit of clandestine garbage, which disqualifies the area for release. The distance between the capture and recapture points, considering the time between these events and the average daily movement of a sloth, corroborate a relatively smaller home range than expected for a 
Table 1. Average, minimum, maximum and standard deviation of five morphological measures taken from 13 Bradypus variegatus adult individuals and two cubs from 2013-2017.

\begin{tabular}{llccccc}
\hline & & $\begin{array}{c}\text { Total } \\
\text { Length }(\mathbf{c m})\end{array}$ & $\begin{array}{c}\text { Thoracic } \\
\text { Circumference }(\mathbf{c m})\end{array}$ & $\begin{array}{c}\text { Tail Lenght } \\
(\mathbf{c m})\end{array}$ & $\begin{array}{c}\text { Wingspan } \\
(\mathbf{c m})\end{array}$ & $\begin{array}{c}\text { Weight } \\
(\mathbf{K g})\end{array}$ \\
\hline Males (N = 8) & Mean & 56.9 & 32.6 & 5.6 & 77.3 & 4.00 \\
& Min. & 53.5 & 22.4 & 4.0 & 65.0 & 3.20 \\
& Max. & 63.0 & 38.0 & 8.0 & 91.6 & 4.60 \\
& SD & 3.19 & 5.19 & 1.55 & 7.49 & 0.65 \\
\hline Females (N = 5) & Mean & 56.9 & 32.1 & 5.7 & 81.0 & 4.10 \\
& Min. & 52.0 & 6.5 & 2.0 & 78.0 & 3.50 \\
& Max. & 61.5 & 46.0 & 7.4 & 88.0 & 4.80 \\
& SD & 3.7 & 15.0 & 2.5 & 4.1 & 0.60 \\
\hline & Cub 1 & 51.0 & 31.5 & & 64.0 & 1.90 \\
& Cub 2 & 42.0 & 23.3 & 5.0 & 46.0 & 1.60 \\
\hline
\end{tabular}

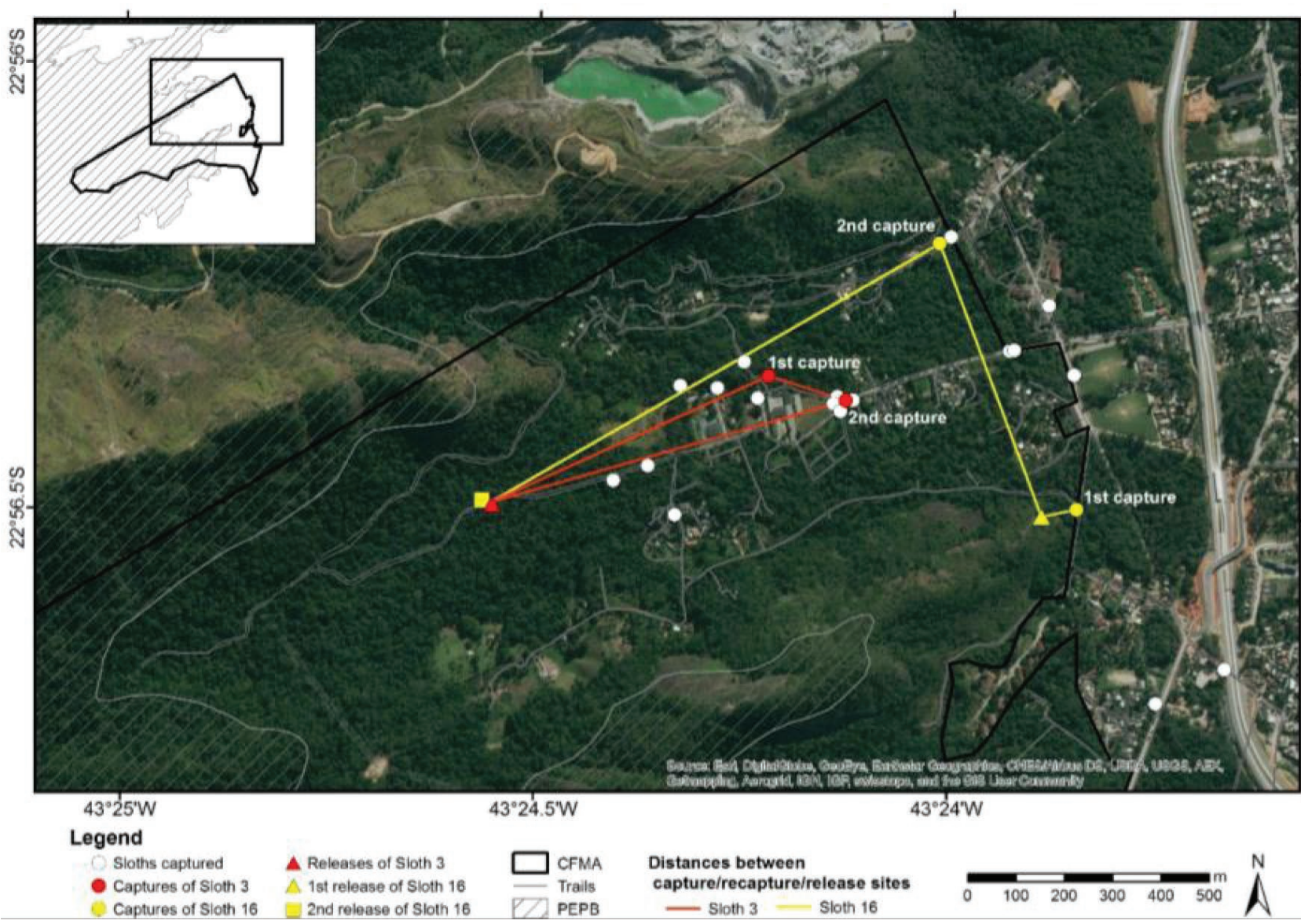

Figure 3. Capture and release sites of sloths in the Campus Fiocruz Mata Atlântica (CFMA-FIOCRUZ) in the surrounding of the Parque Estadual da Pedra Branca (PEPB). Lines (red for Sloth 3 and yellow for Sloth 16) represent the distances among capture, recapture and release sites.

medium-sized mammal described in the literature (Neam \& Lacher 2015).

In August 15, 2013, we rescued an electrocuted sloth that had two of its three claws burned in an electric cable (Figure 5). This animal was taken to a veterinary rehabilitation center (Centro de Reabilitação de Animais Silvestres da Universidade Estácio de Sá - CRAS-UNESA).

On April 10, 2017 we recorded a mating, $35 \mathrm{~m}$ away from the CFMA-FIOCRUZ main building. 
Two sloths attached to each other fell down from a $3 \mathrm{~m}$ high tree. They remained attached after the fall, facing each other, and spent some time together vocalizing, biting and hitting each other (video at https://www.youtube.com/ watch?v=s8xlkbuH9uQ). There are previous reports of copulatory behaviour in B. variegatus, presenting this same continuously vocalization and also with the animals facing each other (Bezerra $e t$ al. 2008). We record it on April, beginning of the wet season, which is in accordance to the mating season described previously for B. variegatus and $B$. torquatus (Laura-Ruiz \& Chiarello 2005).

Average $( \pm \mathrm{SD})$ morphological measures $(\mathrm{N}=$ 13) were: weight $=3.94 \pm 0.65 \mathrm{~kg}$, tail length 5.62 $\pm 1.8 \mathrm{~cm}$ and total body length $56.87 \pm 3.24 \mathrm{~cm}$ (Table 1). Our data were similar to that available in previous studies (Wetzel 1985, Hayssen 2010, Xavier et al. 2015). On Table 1, we presented the data for males, females and cubs separately, but values for males and females were very similar.

Although B. variegatus is listed in CITES Appendix II (2017), in most of its distribution it does not appear to suffer a major threat (MoraesBarros et al. 2014). Sloths are not commonly listed in studies on hunting in the Atlantic Forest (Cassano 2006), however they can be hunted at random events, especially when found on the ground while crossing open areas (Oliver \& Santos 1991). One of the main causes of accidents for $B$. variegatus is electrocution in high tension wires used by the animals as support to move, leading to violent shocks that cause burns, amputations and death (Martínez et al. 2004, Souza-Junior et al.
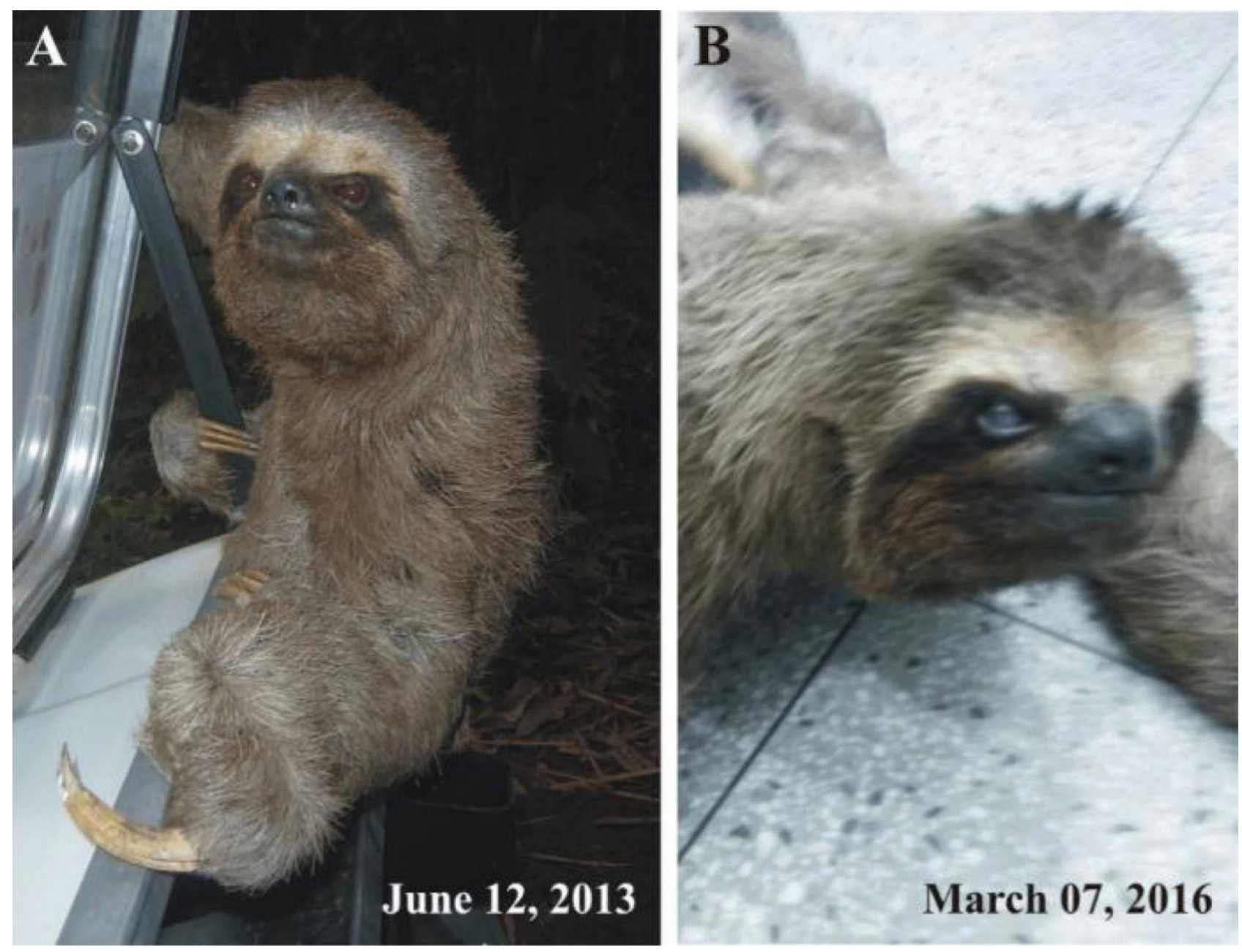

Figure 4. a) Sloth 3 captured on June 12, 2013, showing healthy eyes. b) Sloth 3 recaptured on March 07, 2016, showing injured right eye. 

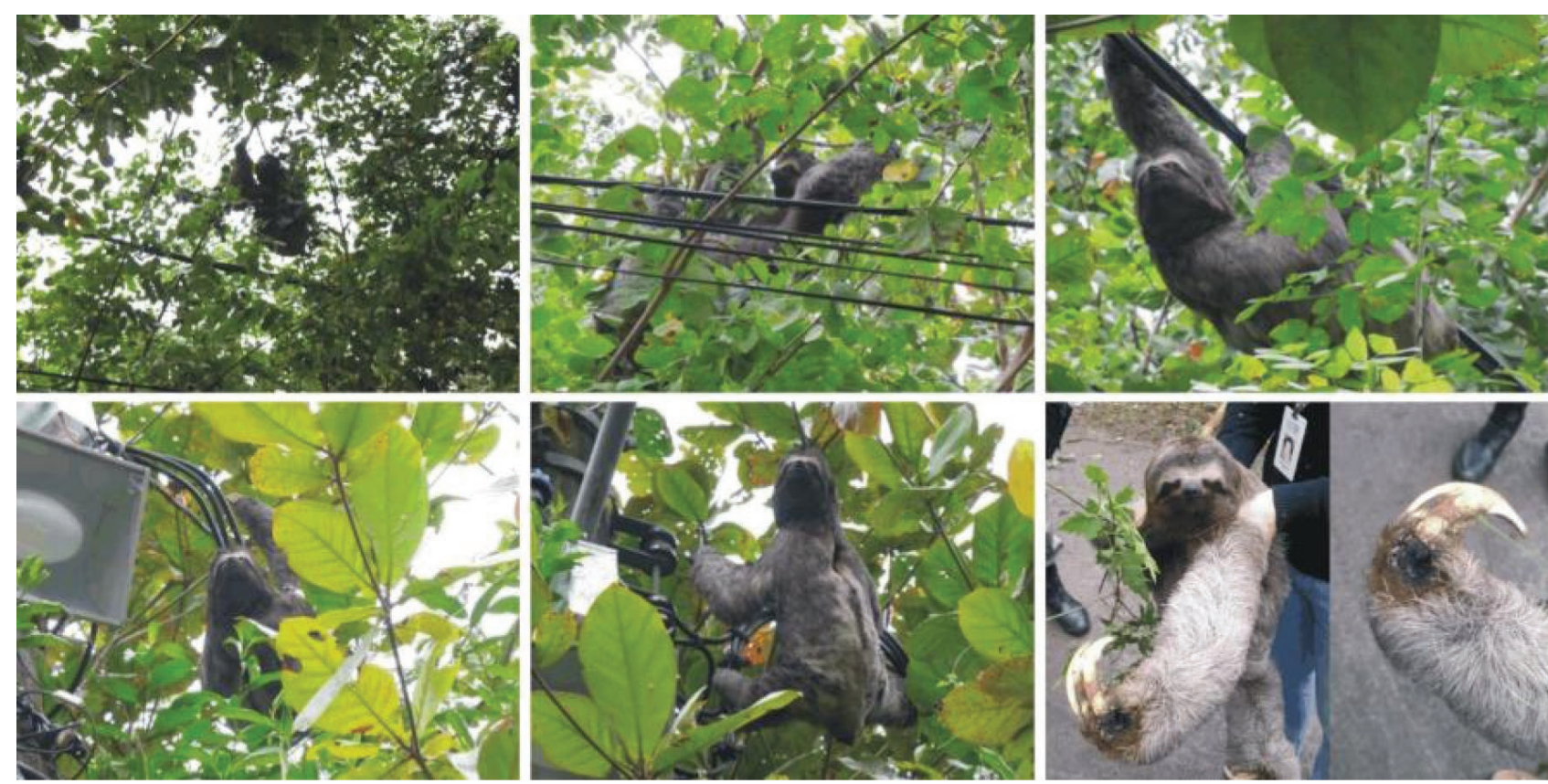

Figure 5. Sequence of images at Campus Fiocruz Mata Atlântica boundaries of an electrocuted Bradypus variegatus resulting in two burned claws.

2010, Lima et al. 2012). The greatest threat for sloths in our studied region seems to be the urbanization. Human occupation of a wild area, including the presence of domestic animals, highway network and electrical grid, increases the risk of accidental events involving sloths.

The monitoring and management of freeliving B. variegatus is rare in Brazil. Xavier et al. (2010), developed and test a temporary marking technique to individually identify free-living brown-throated three-toed sloths, and they could successfully recapture some animals and collect important information about individuals. There is no doubt that temporal marking techniques are useful and sometimes are more suitable than permanent markers, once it is a cheaper technique. The use of microchips in our protocol is important once we also work with wildlife health and we can still monitor each individual for the rest of their lives. Independently of the technique, here we enlighten the importance of the individual identification to improve knowledge in the biology and conservation of this Atlantic Forest species.

Wildlife management is imperative in Brazil. Urban expansion to forested areas are approaching wildlife fauna to humans and it can be a risk for the safety and conservation of animals even though to human health, once wildlife are hosts of many pathogens that can be zoonotic. Knowledge of animal's biology and health of individuals are important points to be explored for the success of the management and in cases as this manuscript, the knowledge of the area of occurrence are essential, for a safe release of animals and future monitoring.

\section{ACKNOWLEDGMENTS}

Thanks for Benjamin Pereira de Souza Júnior and Rodrigo Palazzo for the movie and edition, respectively. Thanks to everyone in the local community who call us to help endangered animals. Thanks to Renato Orsini and Carlos Barbosa Filho during the beginning of this project. Thanks the photographer Lin Lima for the pictures. Special thanks for the revisers that helped to improve this manuscript. This study was partially supported by Fundação de Amparo à Pesquisa do Estado do Rio de Janeiro (FAPERJ), Grant: 41/2013 - EMERGENTES E-26/110.109/2014 and Programa de Desenvolvimento do Campus Fiocruz Mata Atlântica (PDCFMA). FBF holds a grant from Conselho Nacional de Desenvolvimento Científico e Tecnológico (CNPq) for productivity in research. 


\section{REFERENCES}

Bezerra, B. M., Souto, A. S., Halsey, L. G., \& Schiel, N. 2008. Observation of brown-throated three-toed sloths: mating behaviour and the simultaneous nurturing of two young. Journal of Ethology, 26(1), 175-178. DOI: 10.1007/s10164-007-0038-z

Britton, S. W. 1941. Form and function in the sloth (concluded). Quarterly Review of Biology, 16(2), 190-207. DOI: $10.1086 / 394628$

Cassano, C. R. 2006. Ecologia e conservação da preguiça-de-coleira (Bradypus torquatus Illiger, 1811) no sul da Bahia. Master Thesis. Departamento de Zooologia da Universidade Estadual de Santa Cruz. p. 106.

Chiarello, A., \& Members of the Edentate Specialist Group. 2008. Bradypus variegatus. International Union for Conservation of Nature and Natural Resources red list of threatened species. Retrieved 06 April, 2017, from www.iucnredlist. org

CITES - Convention on International Trade on Endangered Species of Wild Fauna and Flora. 2017. Appendices I, II and III. Retrieved on 22 January, 2019, from https://www.cites.org/eng/ app/appendices.php

Divers, B. J. 1986. Edentata. In: M. E. Fowler (Ed.), Zoo and wild animal medicine. 2nd Ed. pp. 621630. Philadelphia, Pennsylvania: W.B. Saunders Co.

Gilmore, D. P., Costa, C. P., \& Duarte, D. P. F. 2001. Sloth biology: an update on their physiological ecology, behavior and role as vectors of arthropods and arboviruses. Brazilian Journal of Medical and Biological Research, 34(1), 9-25. DOI: 10.1590/S0100-879X2001000100002

Hayssen, V. 2010. "Bradypus variegatus (Pilosa: Bradypodidae)”. Mammalian Species, 42(1), 1932. DOI: $10.1644 / 850.1$

Lara-Ruiz, P., \& Chiarello, A. G. 2005. Life-history traits and sexual dimorphism of the Atlantic forest maned sloth Bradypus torquatus (Xenarthra: Bradypodidae). Journal of Zoology, 267(1), 63-73. DOI: 10.1017/S0952836905007259

Lima, D. A. S. D., Lima, W. C., Rodrigues, M. C., Quessada, A. M., Santos, K. M. M., Moura, C. R. C., Magalhães, C. S., \& Sousa, J. M. 2012. Trauma elétrico em preguiça de vida livre: relato de caso. Revista Portuguesa de Ciências Veterinárias, 107(583-584), 199-202.
Martínez, N., Antelo, C., \& Rumiz, D. I. 2004. Rehabilitación de perezosos (Bradypus variegatus) urbanos en Reservas Privadas Aledañas a Santa Cruz De La Sierra: una iniciativa multipropósito de investigación, manejo y educación. Revista Boliviana de Ecología y Conservación Ambiental, 16, 1-10.

Mikich, S. B., \& Bernils, R. S. 2004. Livro vermelho da fauna ameaçada no Estado do Paraná. Curitiba: Instituto Ambiental do Paraná: p. 763.

Montgomery, G. G., \& Sunquist, M. E. 1975. Impact of sloths on Neotropical energy flow and nutrient cycling. In: E. Medina, \& F. Golly (Eds.), Trends in Tropical Ecology. pp. 69-98. New York: Springer Verlag.

Moraes-Barros, N., Chiarello, A., \& Plese, T. 2014. Bradypus variegatus. The IUCN Red List of Threatened Species 2014: e.T3038A47437046. DOI: $\quad 10.2305 /$ IUCN.UK.2014- $\quad 1 . R L T S$. T3038A47437046.en

Neam, K. D., \& Lacher,T.E. 2015. Spatial distribution, resource use, and behavior of brown-throated sloths (Bradypus variegatus) in a multi-use landscape. Edentata, 16, 46-56.

Nowak, R. M. 1999. Walker's Mammals of the World. 6th Ed. Baltimore and London: The Johns Hopkins University Press: p. 836.

Oliver, W. L. R., \& Santos, I. B. 1991. Threatened endemic mammals of the Atlantic Forest region of South-east Brazil. Wildlife Preservation Trust, Special Scientific Report, 4, 21-31.

Pauli, J. N., \& Peery, M. Z. 2012. Unexpected strong polygyny in the brown throated three-toed sloth. PloS one. 7, e51389. DOI: 10.1371/journal. pone.0051389

Pocock, R. I. 1924. The external characters of the South American edentates. Proceedings of the Zoological Society of London, 4, 983-1031. DOI: 10.1111/j.1096-3642.1924.tb03325.x

Queiroz, H. L. 1995. Preguiças e guaribas: os mamíferos folívoros arborícolas do Mamirauá. Brasília: CNPq e Sociedade Civil Mamirauá: p. 160.

Reid, F. 1997. A field guide to the mammals of Central America and southeast Mexico. New York: Oxford University Press: p. 334.

Santos, P. M., Chiarello, A. G., Ribeiro, M. C., Ribeiro, J. W., \& Paglia, A. P. 2016. Local and landscape influences on the habitat occupancy of the endangered Maned Sloth Bradypus torquatus 
within fragmented landscapes. Mammalian Biology, 81(5), 447-454. DOI: 10.1016/j. mambio.2016.06.003

Silva, G. A. O., Paz, M. C. P., \& Cordeiro, T. A. 2017. Monitoramento do bicho-preguiça Bradypus variegatus Schinz, 1825 (Xenarthra: Bradypodidae) em um remanescente de Floresta Atlântica (João Pessoa-PB, Nordeste do Brasil). Revista Brasileira de Gestão Ambiental e Sustentabilidade, 4(8), 299-312.

Souza-Júnior, M. H., Mello, S. A. X., \& Xavier, G. A. A. 2010. Preguiças-de-garganta-marrom Bradypus variegatus habitantes de praças públicas no Município de Rio Tinto, Paraíba. In: G. F. Seabra, J. A. N. Silva, \& I. T. L. Mendonça (Orgs.), A conferência da Terra: aquecimento global, sociedade e biodiversidade. pp. 418-424. João Pessoa: Editora Universitária da UFPB.

Urbani, B., \& Bosque, C. 2007. Feeding ecology and postural behaviour of the three-toed sloth (Bradypus variegatus flaccidus) in northern Venezuela. Mammalian Biology, 76(6), 321-329. DOI: 10.1016/j.mambio.2006.10.013

Walker, E. P. 1991. Mammals of the world. 5th Ed. Baltimore and London: John Hopkins University Press: p. 515.

Wetzel, R. 1985. The identification and distribution of recent Xenarthra (= Edentata). In: G. G. Montgomery (Ed.), The evolution and ecology of armadillos, sloths and vermilinguas. pp. 5-21. Washington and London: Smithsonian Institution Press.

Xavier, G. A. A. 2007. Aspectos clínicos e de manejo de preguiça-de-garganta-marrom Bradypus variegatus (Schinz, 1825) de vida livre na mesorregião metropolitana do Recife, Pernambuco, Brasil. Doctoral thesis. Departamento de Medicina Veterinária da Universidade Federal Rural de Pernambuco. p. 88.

Xavier, G. A. A., Mota, R. A., \& Oliveira, M. A. B. 2010. Marcação ungueal em Preguiças-de-gargantamarrom Bradypus variegatus (Schinz, 1825) de vida livre na Estação Ecológica de Caetés, Paulista-PE, Brasil. Edentata, 11(1), pp. 18-21. DOI: 10.1896/020.011.0104

Xavier, G. A. A., Mourão, G. M., Costa, J. F., \& Moraes-Barros, N. 2015. Avaliação do risco de extinção de Bradypus variegatus Schinz, 1825 no Brasil. Série Estado de Conservação da Fauna Brasileira, 2, 35-54.
Submitted: 03 April 2018

Accepted: 22 January 2019

Published online: 25 January 2019

Associate Editor: Camila dos Santos de Barros 